\title{
Comprehensive Understanding of Roller Milling on the Physicochemical Properties of Red Lentil and Yellow Pea Flours
}

\author{
Manoj Kumar Pulivarthi, Eric Nkurikiye, Jason Watt, Yonghui Li (D) and Kaliramesh Siliveru *(D) \\ Department of Grain Science and Industry, Kansas State University, Manhattan, KS 66506, USA; \\ pmanoj@ksu.edu (M.K.P.); enkurikiye@ksu.edu (E.N.); jwatt1@ksu.edu (J.W.); yonghui@ksu.edu (Y.L.) \\ * Correspondence: kaliramesh@ksu.edu; Tel.: +1-785-532-4071
}

Citation: Pulivarthi, M.K.

Nkurikiye, E.; Watt, J.; Li, Y.; Siliveru, K. Comprehensive Understanding of Roller Milling on the Physicochemical Properties of Red Lentil and Yellow Pea Flours. Processes 2021, 9, 1836. https://doi.org/10.3390/pr9101836

Academic Editor: Bernd Hitzmann

Received: 29 September 2021

Accepted: 11 October 2021

Published: 15 October 2021

Publisher's Note: MDPI stays neutral with regard to jurisdictional claims in published maps and institutional affiliations.

Copyright: (C) 2021 by the authors. Licensee MDPI, Basel, Switzerland. This article is an open access article distributed under the terms and conditions of the Creative Commons Attribution (CC BY) license (https:// creativecommons.org/licenses/by/ $4.0 /)$.

\begin{abstract}
The development of convenience foods by incorporating nutrient-rich pulses such as peas and lentils will tremendously alter the future of pulse and cereal industries. However, these pulses should be size-reduced before being incorporated into many food products. Therefore, an attempt was made to adapt roller mill settings to produce de-husked yellow pea and red lentil flours. The milling flowsheets unique to yellow peas and red lentils were developed in producing small, medium, and large flours with maximum yield and flour quality. This study also investigated the differences in chemical composition, physical characteristics, and particle size distributions of the resultant six flour fractions. The kernel dimensions and physicochemical properties of the whole yellow pea and red lentils were also studied to develop customized mill settings. Overall, the mill settings had a significant effect on the physical properties of different particle-sized flours. The geometric mean diameters of different particle-sized red lentil flours were $56.05 \mu \mathrm{m}$ (small), $67.01 \mu \mathrm{m}$ (medium), and $97.17 \mu \mathrm{m}$ (large), while for yellow pea flours they were $41.38 \mu \mathrm{m}$ (small), $60.81 \mu \mathrm{m}$ (medium), and $98.31 \mu \mathrm{m}$ (large). The particle size distribution of all the flour types showed a bimodal distribution, except for the small-sized yellow pea flour. For both the pulse types, slightly more than $50 \%$ flour was approximately sizing $50 \mu \mathrm{m}, 75 \mu \mathrm{m}$, and $100 \mu \mathrm{m}$ for small, medium, and large settings, respectively. The chemical composition of the flour types remained practically the same for different-sized flours, fulfilling the objective of this current study. The damaged starch values for red lentil and yellow pea flour types increased with a decrease in flour particle size. Based on the Hausner's ratios, the flowability of large-sized flour of red lentils could be described as passable; however, all the remaining five flour types were indicated as either poor or very poor. The findings of this study assist the millers to adapt yellow pea and red lentil milling technologies with minor modifications to the existing facilities. The study also helps in boosting the production of various baking products using pulse and wheat flour blends to enhance their nutritional quality.
\end{abstract}

Keywords: pulses; yellow pea; red lentils; protein; roller milling; particle size

\section{Introduction}

The demand for healthier food choices has been growing with an increase in the consumer's interest for adapting nutrient-rich functional foods in their diets. Even though whole-grain cereal-based convenience products offer a good amount of fiber, vitamins, minerals, and phytochemicals owing to the presence of bran and germ portions, these foods still lack protein to some extent and contain few essential amino acids such as lysine and threonine [1]. Therefore, it is important to fortify the baked products with functional ingredients such as pulses, to further improve the nutritional and health benefits of the end products.

Yellow peas (Pisum sativum L.) and red lentils (Lens culinaris L.), like other pulses, are rich in protein and are highly nutritious, offering all the essential amino acids except for methionine, cysteine, and tryptophan [2]. The limiting amino acid in wheat is lysine, while all pulses have an adequate amount of lysine and lack sulfur-containing amino acids, 
which are essential for competing with the protein quality from animal sources. Therefore, fortification of wheat-based bakery products with pulses is a perfect supplement to offer a balanced proportion of essential amino acids [3].

In recent times, numerous studies have been driven towards the addition of composite flours containing pulses in baked foods [4,5]. The addition of pulse flour has also shown promising results, such as increased protein and antioxidant activity, compared to regular wheat products [6]. Research has shown that the amount/level of pulse flour substituted with wheat affects the quality of the baked product [7]. Depending on the end goal or the objective, the resultant pulse flours can be incorporated into wheat-based bakery products as whole/de-hulled pulse flour, or in the form of refined fractions of protein, fiber, or starch.

The development of convenience foods by incorporating nutrient-rich pulses such as peas and lentils will tremendously alter the future of pulse and cereal industries. However, a standard milling method is still unavailable for generating high-quality pulse flours from raw peas and lentils. These pulses are being milled using various milling techniques such as roller, hammer, ball, and pin mill. Among all these milling methods, roller milling is unique and gives the miller great control over the final quality of the flours as the size reduction takes place gradually over a series of corrugated and smooth set of rolls with varied rotational speeds [8]. A standard and widely used method for producing wheat flour is roller milling. Hence, altering the roller mill settings to produce pea and lentil flour is the best and most economic opportunity for wheat millers, as they could use the wheat-milling equipment to produce pulse flours as well. Additionally, a standard protocol for optimal pretreatments and mill settings for these pulses is needed for upscaling the milling process industrially.

The size reduction of pulses depends on various factors such as pulse kernel characteristics and milling operational parameters. The particle size of the resultant flour can be adjusted by optimizing the mill settings such as roll gaps and sieve sizes. It is an important parameter to predict the performance of milling [9].

Several researchers have already studied the effects of incorporating pulse flours of different particle sizes into wheat-based products [10-12]. It is evident that the final quality of the product is being affected by differences in particle size. However, the majority of these studies reported the use of a single milling process to obtain a single batch of flour with varied particle sizes. The obtained single flour batch was then sieved/segregated to produce multiple flour batches (small, medium, and large). However, a major shortcoming in separating a single batch of flour into different particle sizes led to a change in their chemical composition. Hence, it is important to obtain flours of different particle sizes with the same chemical composition to comprehend the original effect of particle size on the final quality of the convenience foods.

Hence, an attempt has been made to develop different mill settings in a roller mill to obtain small, medium, and large flour fractions from yellow peas and red lentils. The specific objectives were to (a) develop milling flowsheets unique to yellow peas and red lentils in producing small, medium, and large flour fractions with maximum yield and quality; and (b) understand the differences in chemical composition, physical characteristics, and particle size distributions of the resultant flour fractions.

\section{Materials and Methods}

\subsection{Materials}

Two types of pulses, namely, yellow peas from "D'allesandro gourmet online store" and red lentils from "Food to live online store", were received as whole grains with an initial moisture content of $11.88 \pm 0.11 \%$ and $10.6 \pm 0.58 \%$ in wet basis (w.b.), respectively. The moisture content of these grains was determined by drying 10 gram $(\mathrm{g})$ of grain samples, in triplicate, at $105^{\circ} \mathrm{C}$ for 72 hours (h) in a hot-air convection oven. 


\subsection{Methods}

\subsubsection{Kernel Characteristics}

The kernel characteristics of red lentils and yellow peas were studied by randomly collecting 100 grains each from the sample lots. The linear dimensions such as length $(L)$, width $(W)$, and thickness $(T)$ for each kernel were determined using a digital caliper (General Tools and Instruments LLC, Secaucus, NJ, USA) of $0.01 \mathrm{~mm}$ accuracy.

The equations given by Mohsenin [13] were used to further deduce the average diameter of the pulses with the help of linear dimensions $(L, W$, and $T)$. The arithmetic mean diameter $\left(D_{a}\right)$ and geometric mean diameter $\left(D_{g}\right)$ of the pulse grains were calculated using the below Equations (1) and (2), respectively. Similarly, the sphericity values $(\Phi)$ were obtained from the Equation (3) [13].

$$
\begin{gathered}
D_{a}=(L+W+T) / 3 \\
D_{g}=(L W T)^{\frac{1}{3}} \\
\Phi=\frac{(L W T)^{\frac{1}{3}}}{L}
\end{gathered}
$$

\subsubsection{Tempering}

The preliminary milling trials (not shown) conducted at various tempering moisture and time combinations indicated $12 \%$ moisture content for $18 \mathrm{~h}$ to be ideal for both yellow peas and red lentils for maximum yield. The amount of water $(Q, \mathrm{~mL})$ to be added to achieve the above-mentioned moisture level was calculated from the following Equation (4).

$$
Q=w \frac{(m f-m i)}{100-m f}
$$

where $w=$ weight of grains to be tempered in grams, $m f=$ desired grain moisture $(\%)$, and $m i$ is initial grain moisture (\%).

The initial conditioning or uniform mixing of water to the yellow peas and red lentils was obtained by mixing in power-driven rotary bins for $30 \mathrm{~min}$ and further storing these pulses in airtight resealable bags for $18 \mathrm{~h}$ at room temperature.

\subsubsection{Milling}

The yellow peas and red lentils were milled using a bench top stainless steel roller mill (Model 915, Ross Machine and Mill Supply, Oklahoma City, OK, USA). After conducting several preliminary trials, the milling flowsheets were developed to obtain three differentsized flours (small, medium, and large) for each of the pulse types. The particle sizes of these small, medium, and large flours were aimed to be $\leq 75 \mu \mathrm{m}, \leq 150 \mu \mathrm{m}$, and $\leq 200 \mu \mathrm{m}$, respectively. The number of break rolls and smooth rolls for milling varied with type of pulse used and desired flour size. The mill settings were designed to separate the hull portions completely from the flour fractions. The flour fractions were being sieved after each pass of the milling using a gyratory sifting box (Great Western Manufacturing, Leavenworth, KS, USA) with the sieves mentioned in the flowsheets below in results section (Figures 1 and 2). As we progress through each pass, the corrugations on the reduction rolls varied from 15 teeth/inch to 22 teeth/inch, whereas there were no corrugations on the reduction rolls. The differential speed between the pair of rolls also varied between reduction rolls and break rolls. The roll size, differential speed, number of corrugations per inch, and roller gap between the rolls were varied in the milling process as cited below in Figures 1 and 2. The milling of these pulses was conducted in triplicates, and the fractions such as hull, shorts, and flour were individually weighed to determine the 
milling performance. The milling yield (\%) for all the six milling conditions was calculated using Equation (5) mentioned below.

$$
\text { Milling Yield }(\%)=\frac{\text { Weight of flour fraction }}{\text { Weight of pulses }} \times 100
$$

\subsubsection{Proximate Analysis}

The moisture content of the flour fractions post milling was determined by heating $2-3 \mathrm{~g}$ of flour sample in hot air oven at $135^{\circ} \mathrm{C}$ for $2 \mathrm{~h}$ according to AACC 44-19.01 method [14]. The moisture content is expressed in percent wet basis throughout the manuscript.

The proximate composition of the whole-grain and flour fractions of yellow peas and red lentils was determined through an external lab. The methods used include AACC Method 46-30 for crude protein [15], AACC method 30-10 for crude fat [16], AACC Method 32-10 for crude fiber [17], and AACC Method 08-01 for ash content [18]. The percent of total carbohydrate contents excluding fiber in the grain and flour samples was determined by subtracting the protein, fiber, fat, ash, and moisture content from 100.

The AACC 76-33.01 method [19] was followed to determine the damaged starch content of the yellow pea and red lentil flour fractions using an SDmaticTM (Chopin Technologies, Villeneuve la Garenne, France).

\subsubsection{Particle Size Distribution}

An alpine jet sieve (Hosokawa Micron, E200 LS) was used to measure the particle size distributions (PSD) of the small, medium, and large flours obtained from yellow peas and red lentils.

The ASTM standard sieve sizes used for understanding the granulation ranges from $25 \mu \mathrm{m}$ to $250 \mu \mathrm{m}$. The analysis was carried out in triplicates by taking $100 \mathrm{~g}$ of flour for each run. The PSD was measured based on the amount of flour $(\mathrm{g})$ passing through the sieves as described by Rivera et al. [20].

Additionally, by measuring the weights of flour retained over each sieve, the geometric mean diameter $\left(d_{g w}\right)$ was calculated using the following expression for all the six types of flour fractions [21].

$$
d_{g w}=\log ^{-1}\left[\frac{\sum_{i=1}^{n}\left(W_{i} \log \bar{d}_{i}\right)}{\sum_{i=1}^{n} W_{i}}\right]
$$

where $W_{i}$ is amount of flour retained on $i^{\prime}$ th sieve $(\mathrm{g}), n$ is the total number of sieves, and $d_{i}$ is aperture size of the $i^{\prime}$ th sieve.

\subsubsection{Color Analysis}

The color values $\left(\mathrm{L}^{*}, \mathrm{a}^{*}\right.$, and $\left.\mathrm{b}^{*}\right)$ for the grain and flour fractions of yellow pea and red lentils were measured using a Miniscan EZ 4500 colorimeter (Hunter lab, Reston, VA, USA) [5]. The results were reported based on triplicates.

\subsubsection{Bulk Density}

The bulk density of the whole yellow peas, red lentils, and their respective flour fractions was measured using a standard Winchester cup arrangement (Seedburo Equipment Co., Des Plaines, IL, USA). The sample was allowed to fall from a height of $10 \mathrm{~cm}$ into an empty cup until it overflows. A scrapper was used to remove the excess sample over the cup, and the bulk density was measured by taking the final sample weight (g) and cup volume in triplicates using expression 7 below.

$$
\text { Bulk Density }=\frac{\text { Weight of Sample }(\mathrm{g})}{\text { Volume }\left(\mathrm{cm}^{3}\right)}
$$




\subsubsection{Tapped Density}

The tapped density, also known as the compacted density of the whole yellow peas, red lentils and their respective flour fractions, was obtained using an Autotap density analyzer (Quantachrome Instruments, Boynton Beach, FL, USA). The setup consisted of a measuring cylinder of known volume connected to the tapping mechanism. The measuring cylinder was filled with a known amount of sample (g), and then the volume occupied by the sample after 750 taps was measured in triplicates using expression 8 below.

$$
\text { Tap Density }=\frac{\text { Weight of Sample }(\mathrm{g})}{\text { Tapped Volume }\left(\mathrm{cm}^{3}\right)}
$$

\subsubsection{True Density}

The true density of the whole yellow peas, red lentils and their respective flour fractions was measured using helium gas pycnometer (AccuPync II 1340, Micromeritics, Norcross, Georgia). The helium gas was passed through the chamber to determine the volume occupied by solid particles by filling the pore spaces between and within the grain/flour fractions. The weight and volume occupied by the sample were used to obtain true density. The mean value of true densities was obtained from three replications for each sample.

The Hausner's ratio and porosity of the flour samples were determined from the following Equations (9) and (10). Hausner's ratio is a flow factor and can be used to approximate the flowability of flour particles.

$$
\begin{gathered}
\text { Hausner's ratio }=\frac{\text { Tap density }}{\text { Bulk density }} \\
\text { Porosity }=\left(1-\frac{\text { Bulk density }}{\text { True density }}\right) \times 100
\end{gathered}
$$

\subsection{Statistical Analysis}

The analysis of variance (ANOVA) and Tukey's test at a significance level of 0.05 were performed using SAS studio (SAS Institute, Cary, NC, USA) to analyze the statistical significance and differences in means.

\section{Results and Discussion}

\subsection{Grain Characteristics}

The understanding of raw material composition and its properties is crucial in designing handling, processing, and milling processes. The relation between a grain's physical properties and the milling properties has been well established from the beginning of grain processing industries. The density of a grain is one of the widely used quality indexes for predicting the soundness of a kernel [22].

The physicochemical properties evaluated for whole-grain red lentils and yellow peas are summarized in Table 1. The differences among the kernel dimensions are obvious among the red lentils and yellow peas. The geometric and arithmetic diameters of the red lentils ( $3.77 \mathrm{~mm}$ and $3.42 \mathrm{~mm}$, respectively) were much smaller than the yellow peas (6.61 $\mathrm{mm}$ and $6.48 \mathrm{~mm}$, respectively). The arithmetic and geometric mean diameters, and sphericity values of red lentil variety: Seyran-96 from the study conducted by Gürsoy and Güzel [23] matches with the results of red lentils in present study. The higher sphericity value for yellow peas $(92.99 \%)$ compared to red lentils (76.54\%) suggests that the shape of yellow peas tends to be more spherical in nature. The bulk, tap, and true densities of red lentils were observed to be significantly $(p \leq 0.05)$ higher than yellow peas. Additionally, density values of red lentils were found to be much higher than the values reported by Kumar et al. [24]. The moisture content of the red lentils and yellow peas before tempering was found to be $10.6 \%$ and $11.88 \%$ (w.b), respectively, with no significant 
$(p \leq 0.05)$ difference. The protein content of red lentils $(24.48 \%)$ was much higher compared to yellow peas $(20.07 \%)$ and slightly lower than the values reported by Roy et al. [25]. The crude fiber contents for red lentils and yellow peas were $3.33 \%$ and $5.29 \%$, respectively. The toughening effect of pulses during the size reduction process was due to the presence of crude fiber [26]. Finally, the physicochemical properties (except for moisture and carbohydrates) of both the pulses were significantly different and required distinct mill settings. Additionally, the overall proximate composition of the pulses reaffirms the importance of utilizing these pulses in baking sector to enhance the nutritional quality of final product.

Table 1. Physicochemical properties of pulses.

\begin{tabular}{ccc}
\hline Test Variable & Red Lentils & Yellow Peas \\
\hline Arithmetic mean diameter $(\mathrm{mm})$ & $3.77 \pm 0.26^{\mathrm{b}}$ & $6.61 \pm 0.37^{\mathrm{a}}$ \\
Geometric mean diameter $(\mathrm{mm})$ & $3.42 \pm 0.22^{\mathrm{b}}$ & $6.48 \pm 0.37^{\mathrm{a}}$ \\
Sphericity $(\%)$ & $76.54 \pm 1.82^{\mathrm{b}}$ & $92.99 \pm 4.2^{\mathrm{a}}$ \\
Bulk density $\left(\mathrm{kg} / \mathrm{m}^{3}\right)$ & $815.43 \pm 3.76^{\mathrm{a}}$ & $759.73 \pm 3.39^{\mathrm{b}}$ \\
Tap density $\left(\mathrm{kg} / \mathrm{m}^{3}\right)$ & $866.41 \pm 1.15^{\mathrm{a}}$ & $820.67 \pm 2.08^{\mathrm{b}}$ \\
True Density $\left(\mathrm{kg} / \mathrm{m}^{3}\right)$ & $1419.87 \pm 1.33^{\mathrm{a}}$ & $1407 \pm 0.36^{\mathrm{b}}$ \\
$\mathrm{L}^{*}$ (0- black to 100-white) & $62.39 \pm 0.92^{\mathrm{a}}$ & $42.40 \pm 0.05^{\mathrm{b}}$ \\
$\mathrm{a}^{*}$ (-green to $\left.+\mathrm{red}\right)$ & $9.07 \pm 0.14^{\mathrm{a}}$ & $6.94 \pm 0.90^{\mathrm{b}}$ \\
$\mathrm{b}^{*}$ (-blue to +yellow) & $13.84 \pm 0.20^{\mathrm{b}}$ & $20.03 \pm 1.26^{\mathrm{a}}$ \\
1000 Kernel weight $(\mathrm{g})$ & $19.2 \pm 0.38^{\mathrm{b}}$ & $224.8 \pm 0.79^{\mathrm{a}}$ \\
Moisture $(\%$ wet basis) & $10.6 \pm 0.58^{\mathrm{a}}$ & $11.88 \pm 0.11^{\mathrm{a}}$ \\
Crude protein $(\%)$ & $24.48 \pm 0.01^{\mathrm{a}}$ & $20.07 \pm 0.06^{\mathrm{b}}$ \\
Crude fat $(\%)$ & $0.38 \pm 0.01^{\mathrm{b}}$ & $0.9 \pm 0.09^{\mathrm{a}}$ \\
Crude fiber $(\%)$ & $3.33 \pm 0.12^{\mathrm{b}}$ & $5.29 \pm 0.05^{\mathrm{a}}$ \\
Ash (\%) & $2.32 \pm 0.00^{\mathrm{b}}$ & $2.47 \pm 0.01^{\mathrm{a}}$ \\
Total carbohydrates excluding crude fiber $(\%)$ & $59.9 \pm 0.45^{\mathrm{a}}$ & $60.4 \pm 0.07^{\mathrm{a}}$ \\
\hline The different super scripts for mean values in each row are significantly different $(p \leq 0.05)$.
\end{tabular}

\subsection{Development of Milling Flowsheets}

The optimized roller milling flowsheets for obtaining de-husked yellow pea and red lentil flours in three different particle sizes, namely, small $-\mathrm{S}$, medium $-\mathrm{M}$, and large $-\mathrm{L}$, are shown in Figures 1 and 2. The flour sizes for both red lentil flour and yellow pea flour are referred as $\mathrm{S}, \mathrm{M}$, and $\mathrm{L}$ throughout the manuscript. All the flowsheets were optimized after conducting numerous trials on roller mills to obtain maximum husk separation for a designated particle size. The major differences between the mill settings for obtaining red lentil and yellow pea flours of different sizes are highlighted (Figures 1 and 2) for easy identification. The changes w.r.t roller gaps are shown in red font, and sieves are marked in blue background.

Initially, tempering trials were conducted on both the pulses for optimizing the tempering moisture and time for achieving maximum flour yield with the highest bran separation. The tempering trials (data not shown) suggested that a $12 \%$ moisture content on wet basis for 18 hours (h) time period resulted in the highest flour recovery with efficient bran separation.

\subsubsection{Red Lentil Flour Mill Settings}

To obtain a small particle sized flour, the red lentils were milled step wise as indicated in the Figure 1a, i.e., the tempered grains were initially passed through the first break roll (1BK) adjusted to a roller gap (RG) of 0.025 inches. The roller gap was adjusted based on the size of the lentil kernels. It is important to make sure that the gap is not too large for the grain to pass through the break rolls without grinding. Similarly, the gap should not be too small to let the grains bounce off from the rolls. After the first pass, the milled output was passed through a set of three sieves: $1041 \mu \mathrm{m}, 630 \mu \mathrm{m}$, and $75 \mu \mathrm{m}$, as mentioned in Figure 1a. The particles retained over $1041 \mu \mathrm{m}$ were further passed through second break roll, adjusted 
to a roller gap of 0.012 inches. The particles above $630 \mu \mathrm{m}$ were allowed to pass through a third break roll set at 0.006 inches roller gap, and the particles above $75 \mu \mathrm{m}$ were passed into the first reduction roll or $1 \mathrm{M}$ (Middling) passage through a roller gap of 0.003 inches. The product collected in pan under the $75 \mu \mathrm{m}$ sieve was separated as flour after every single pass. In similar fashion, different sieve sets were used as mentioned below in Figure 1a for all the subsequent passes. The coarse hull was obtained over the sieve $1041 \mu \mathrm{m}$ after second pass (2BK), and fine hull was obtained after the third pass (3BK) and first reduction pass or $1 \mathrm{M}$ pass over the $630 \mu \mathrm{m}$ sieve and $425 \mu \mathrm{m}$ sieve, respectively. Shorts, the inseparable mixture of bran and endosperm were collected over $425 \mu \mathrm{m}$ sieve from $2 \mathrm{nd}$, 3rd, and 4 th reduction passes (or 2M, 3M, and $4 \mathrm{M}$ passes). However, in case of medium and large flours, shorts were obtained right from $1 \mathrm{M}$ to $4 \mathrm{M}$ passes, as shown in Figure $1 \mathrm{~b}, \mathrm{c}$.

Even though flour was being collected after each pass in the milling process, most of it was produced after the first reduction pass (1M). The reduction roll passes (2M, 3M and $4 \mathrm{M})$ mentioned in the flowsheet below were individual passes through the smooth rolls to obtain maximum yield and reduce the size of particles to below $75 \mu \mathrm{m}, 150 \mu \mathrm{m}$ and $200 \mu \mathrm{m}$ for small, medium, and large mill settings, respectively.

Similarly, the medium sized lentil flour was produced as per the mill settings shown below in Figure 1b. The number and type of passes used for milling remain constant for small, medium, and large mill settings. However, the key difference between the small and medium size flour settings includes altering the sieve size used at the bottom for flour collection i.e., $150 \mu \mathrm{m}$. Additionally, the roller gap used for reduction rolls remains 0.003 inches for all the four passes to get a medium sized flour.

The same series of rolls used in small and medium mill settings was followed in producing the large lentil flour with minor modifications in roller gaps and sieves as shown in Figure 1c. The sieve size used at the bottom of the sifter for separating flour was $200 \mu \mathrm{m}$ for all the seven passes. Since the objective of this mill setting was to produce large flour, the roller gap for reduction roll passes was slightly bigger than the small and medium mill settings. However, identical roller gaps to the small and medium flour settings were used for all the break rolls since they play a major role in break opening the kernels and separating the husk from endosperm. As the average particle size of the flour has to be higher than small and medium flours, the roller gap for the first set of reduction rolls was adjusted to 0.004 inches and subsequent passes were run at gap of 0.003 inches.

a)
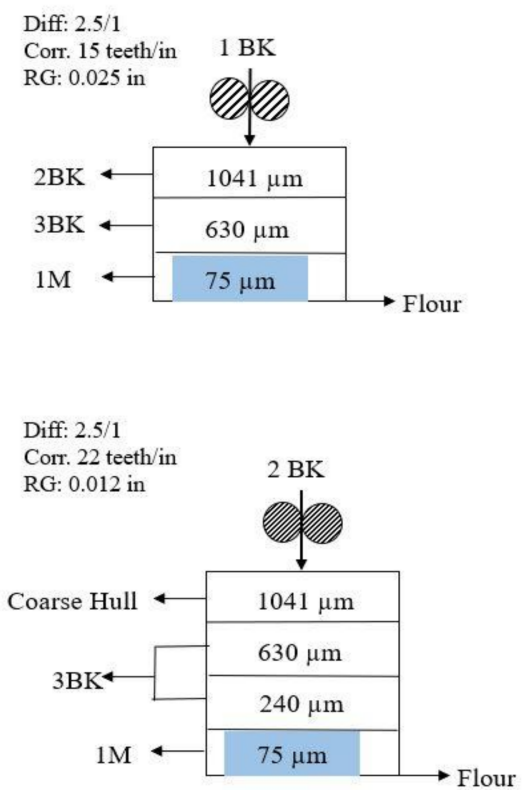

Red lentil small size flour settings
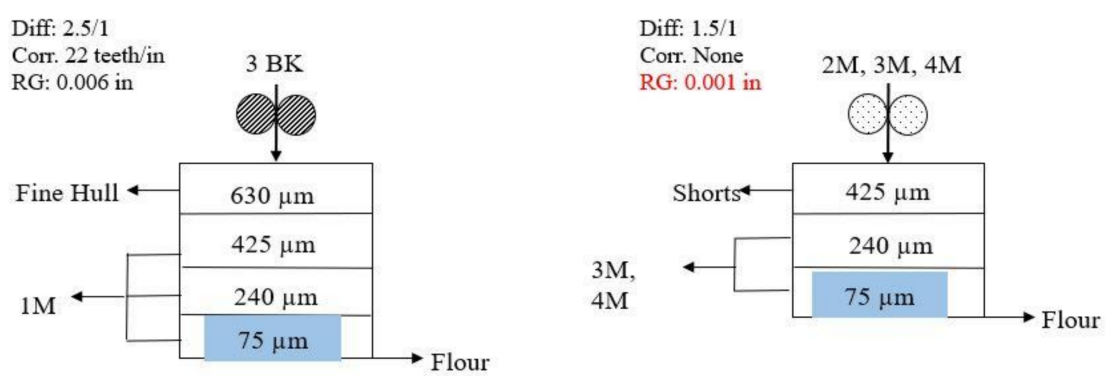

Figure 1. Cont. 
b)

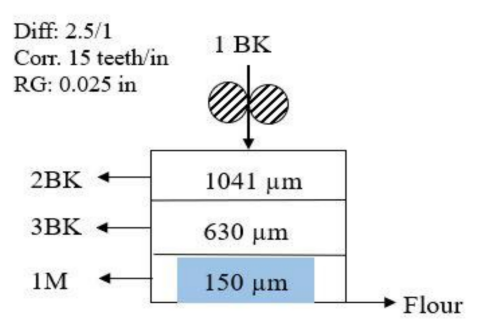

Red lentil medium size flour settings
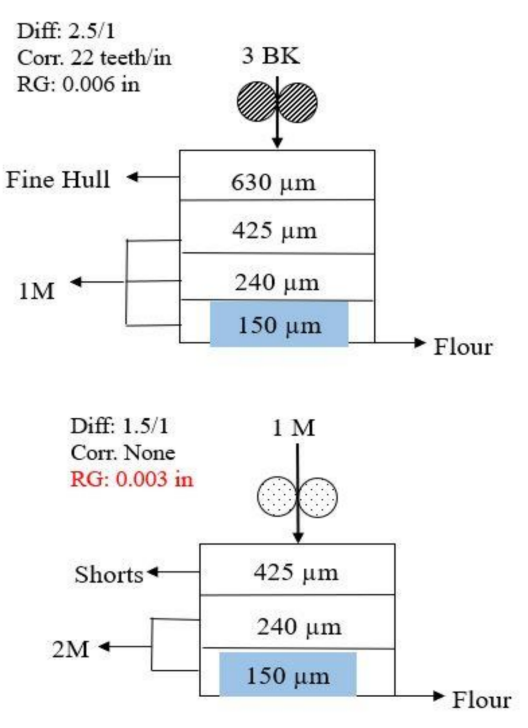

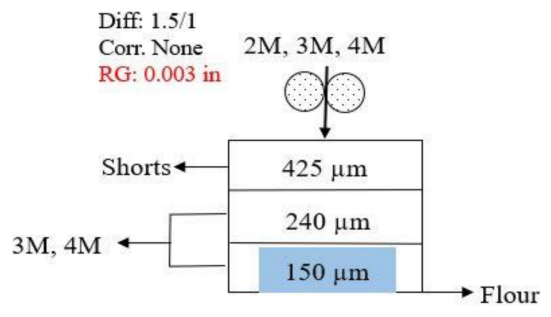

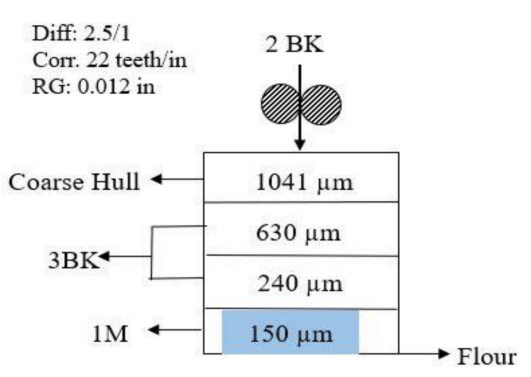

Figure 1. Roller milling flowsheet to obtain (a) small red lentil flour $(\leq 75 \mu \mathrm{m}),(\mathbf{b})$ medium red lentil flour $(\leq 150 \mu \mathrm{m})$, and (c) large red lentil flour ( $\leq 200 \mu \mathrm{m})$; (Diff-Differential speed; Corr—Corrugations; RG—Roller Gap; BK—Break, M-Middling).

\subsubsection{Yellow Pea Flour Mill Settings}

The mill settings developed for obtaining de-husked yellow pea flours greatly differ from that of red lentil flours. The differences in the kernel and shape characteristics observed in Table 1 for both the pulses necessitates customized flow sheets based on individual grain requirements. Since the yellow peas are in different shape and much larger in size and diameter compared to red lentils (Table 1), the mill settings applied were more aggressive. For small, medium, and large yellow pea flours, the series of rolls and number of passes remain constant, as shown in Figure 2. Same set of sieves $(75 \mu \mathrm{m}, 150 \mu \mathrm{m}$, and $200 \mu \mathrm{m}$ ) similar to red lentil flour settings was used at the very bottom in each pass for separating flour fractions to achieve small, medium, and large flours. A total of four break roll passes were needed to bring down the particle size of milled fractions for subsequent reduction roll milling. Among these four break roll passes, the corrugations for the first two sets were 15 teeth/inch and the remaining two had 22 teeth/inch.

In all the three mill flowsheets of yellow peas, a larger roller gap of 0.11 inches was set for the break rolls in first pass (1BK) to break open the pea kernels. The resultant milled fraction obtained was further passed through a set of sieves, as indicated in Figure 2. Unlike red lentils, the first husk separation took place in third break roll pass (3BK) over a $1041 \mu \mathrm{m}$ screen. The fine hull was separated from top of $630 \mu \mathrm{m}$ sieve at the fourth break roll pass (4BK), whereas shorts were separated over a $240 \mu \mathrm{m}$ size screen in all the reduction roll passes.

Roller gaps of 0.055 inches and 0.012 inches were set for second and third set of break rolls, respectively, in all the three milling flowsheets. However, the roller gap settings were altered from 4 th to final step to obtain desired flour sizes. In cases of small and medium yellow pea flour types, roller gaps of 0.006 inches and 0.003 inches were used during the fourth (4BK) and fifth $(1 \mathrm{M})$ passes, respectively. The smallest roller gap, 0.001 inches, was used exclusively for producing small flour during the 2nd, 3rd, and 4th reduction passes. In case of medium flour settings, the roller gap (0.003 inches) remained constant throughout the reduction roll passes to avoid particles from excessive grinding. This is a crucial distinguishing step for achieving the medium flour particles set to pass through a $150 \mu \mathrm{m}$ sieve.

In case of large flour settings, slightly bigger roller gaps (0.006 inches-1M pass and 0.004 inches- $2 \mathrm{M}$ to $4 \mathrm{M}$ passes) were introduced, which is uncommon for a reduction roll 
milling step. Unlike red lentils, the yellow peas tend to grind more readily to a smaller particle size, even at a larger roller gap. Hence, the large yellow pea flour settings used in this study for a reduction roll pass are unique.

a)
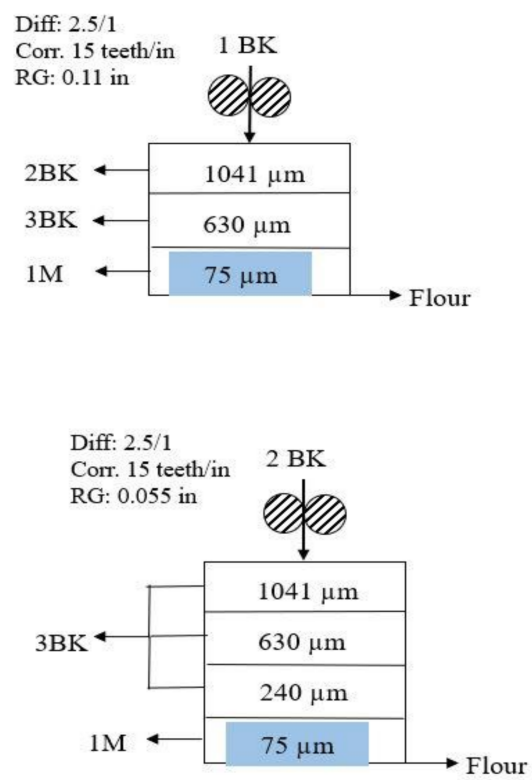

b)
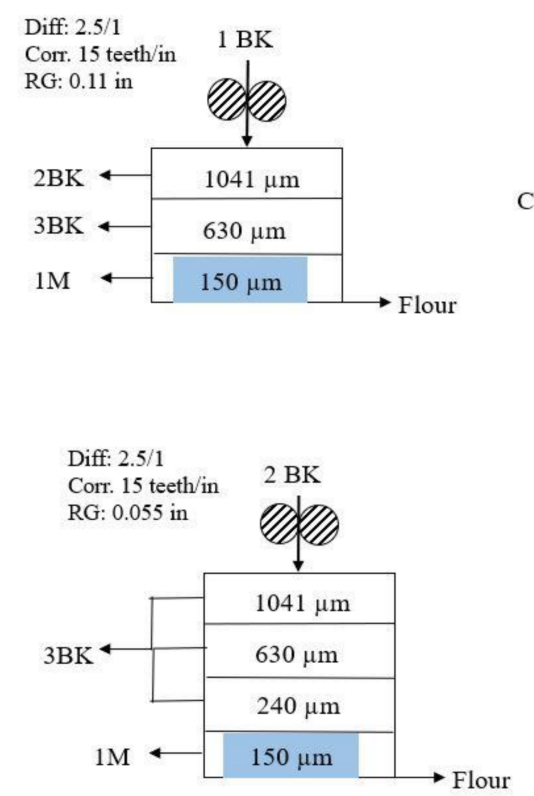

Yellow pea small size flour settings
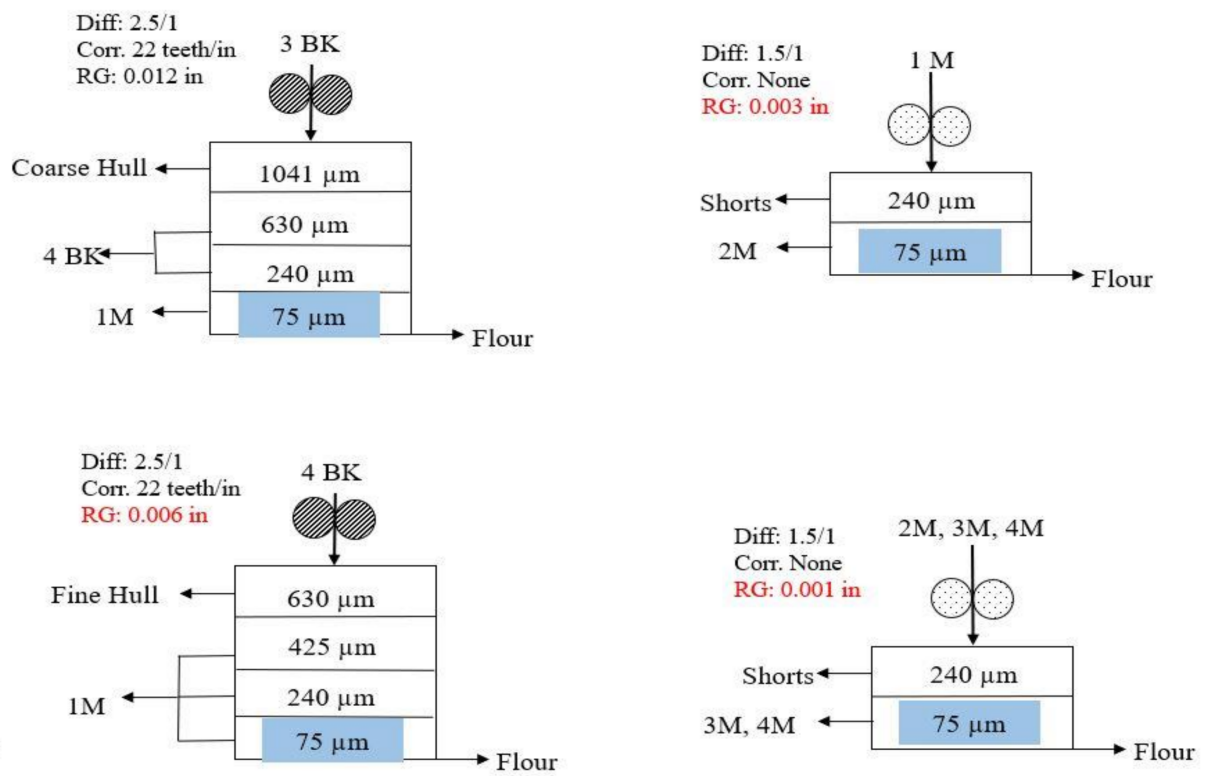

Yellow pea medium size flour settings
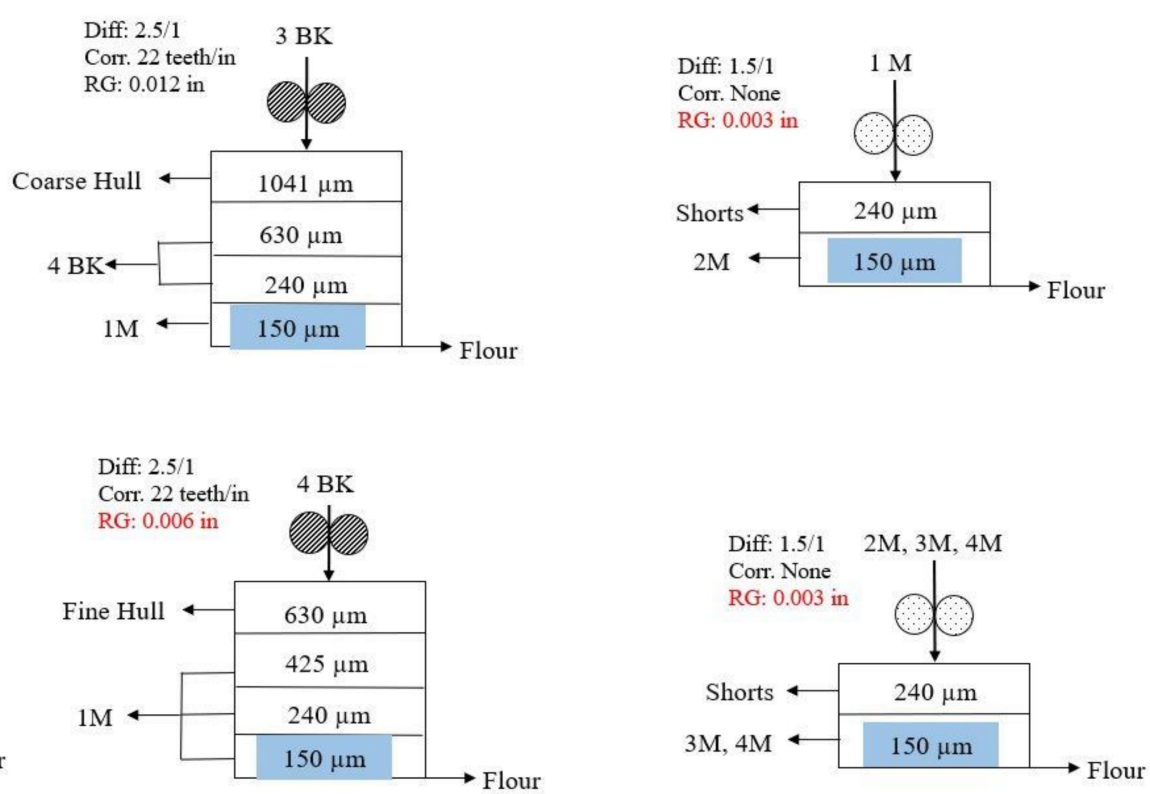

Figure 2. Cont. 
c)
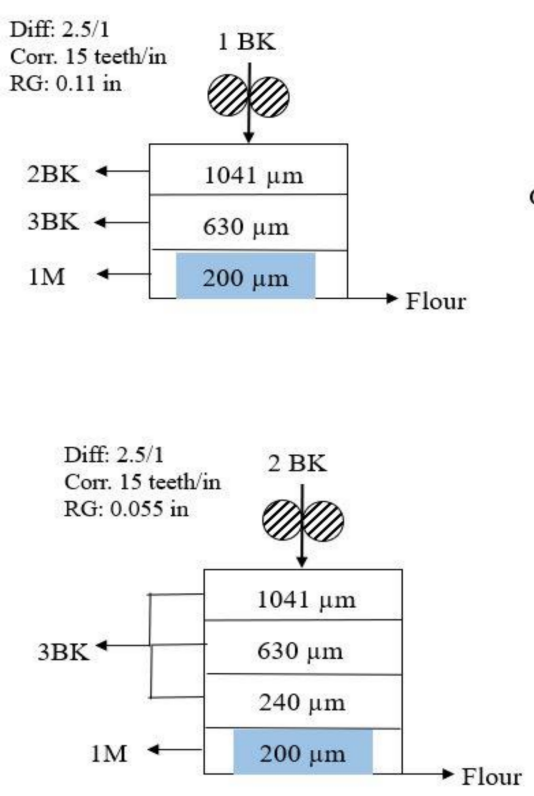

Yellow pea large size flour settings
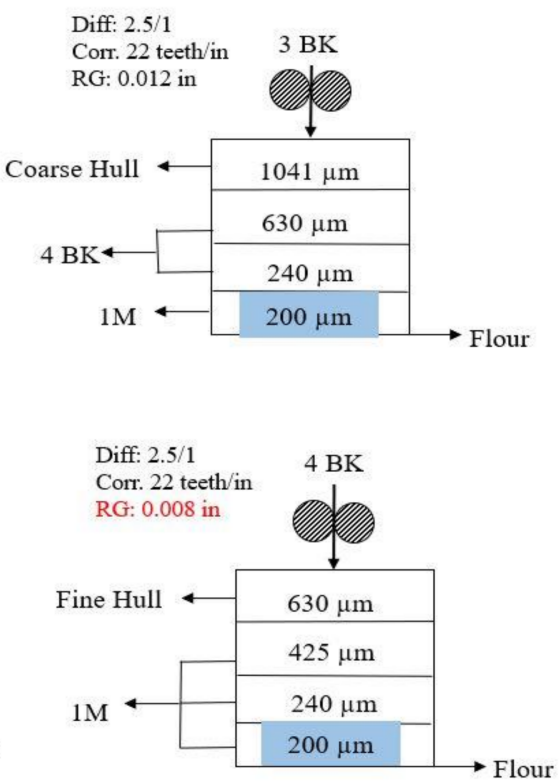
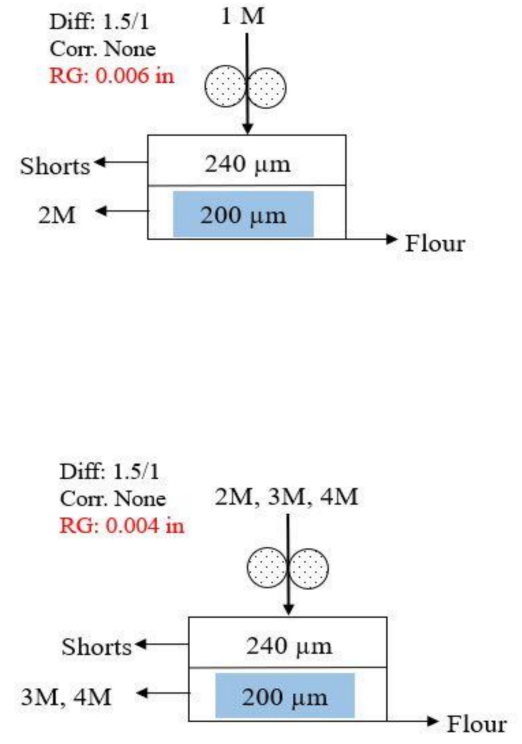

Figure 2. Roller milling flowsheet to obtain (a) small yellow pea flour $(\leq 75 \mu \mathrm{m})$, (b) medium yellow pea flour $(\leq 150 \mu \mathrm{m})$, and (c) large yellow pea flour $(\leq 200 \mu \mathrm{m})$; (Diff—Differential speed; Corr—Corrugations; RG—Roller Gap; BK—Break, M-Middling).

\subsection{Milling Yield}

The milling yields in terms of bran, shorts, and flour are presented in Table 2. The highest flour recovery for red lentil flour was obtained for small flour settings. The target particle size had a significant $(p \leq 0.05)$ effect on all three red lentil flour yields. Additionally, the flour yield $(84.86-82.27 \%$ ) followed a decreasing trend by moving from small to large particle size settings. The bran portions of red lentils ranged from 9.71 to $10.15 \%$, with no significant differences amongst the flour types. However, the amount of dietary fiber present in the lentil kernels was found to be small: $3.3 \%$. This could be due to the presence of some portion of endosperm in bran yields. Additionally, the crude fiber value only signifies the amount of insoluble fiber. The shorts resulted from milling process increased with increase in particle sizes of flours.

Table 2. Milling yields (\% as -is) of red lentils and yellow peas from roller mill.

\begin{tabular}{ccccc}
\hline Sample & Type & Flour & Bran & Shorts \\
\hline \multirow{3}{*}{ Red Lentils } & S & $84.86 \pm 0.19^{\mathrm{a}}$ & $10.15 \pm 0.48^{\mathrm{a}}$ & $3.31 \pm 0.2^{\mathrm{a}}$ \\
& $\mathrm{M}$ & $83.74 \pm 0.42^{\mathrm{b}}$ & $9.92 \pm 0.23^{\mathrm{a}}$ & $3.84 \pm 0.59^{\mathrm{ab}}$ \\
& $\mathrm{L}$ & $82.27 \pm 0.28^{\mathrm{c}}$ & $9.71 \pm 0.22^{\mathrm{a}}$ & $4.26 \pm 0.08^{\mathrm{b}}$ \\
Yellow peas & $\mathrm{S}$ & $82.55 \pm 0.37^{\mathrm{C}}$ & $9.84 \pm 0.12^{\mathrm{A}}$ & $3.84 \pm 0.10^{\mathrm{B}}$ \\
& $\mathrm{M}$ & $84.07 \pm 0.17^{\mathrm{B}}$ & $9.45 \pm 0.07^{\mathrm{B}}$ & $4.85 \pm 0.10^{\mathrm{A}}$ \\
& $\mathrm{L}$ & $86.86 \pm 0.36^{\mathrm{A}}$ & $8.61 \pm 0.10^{\mathrm{C}}$ & $3.45 \pm 0.08^{\mathrm{C}}$
\end{tabular}

Mean values with different lower-case letters in each column are significantly different for red lentils $(p \leq 0.05)$ mean values with different upper-case letters in each column are significantly different for yellow peas $(p \leq 0.05)$.

In case of yellow pea flour settings, the highest flour recovery $(86.86 \%)$ was achieved for large flour settings followed by medium flour (84.07\%). The yellow pea flour yield significantly increased $(82.55-86.86 \%)$ with increase in particle size, whereas bran content declined from 9.84 to $8.61 \%$. Highest bran separation was achieved for small yellow pea flour settings. The change in particle size flour settings produced a significant difference among yields of all the three components. 


\subsection{Particle Diameter and Particle Size Analysis}

The geometric mean diameter for all the three flour sizes of red lentil and yellow pea flours is given in Table 3. The performance and the resultant average size of the six flours milled were determined to understand the degree of difference between the flours with respect to particle sizes. This calculation was obtained from the amount of flour retained on each sieve during the granulation analysis in alpine jet sieve [21]. It was necessary to develop the flowsheets to produce $\geq 98 \%$ of the flour particles below $212 \mu \mathrm{m}$ as per the definition given by Code of Federal Regulations for wheat flour [27]. However, the commercial pulse flours available in the market did not comply with the definition of flour as per the above criteria [26].

Table 3. Geometric mean diameter of red lentil and yellow pea flours.

\begin{tabular}{ccc}
\hline \multirow{2}{*}{ Flour Type } & \multicolumn{2}{c}{ Geometric Mean Diameter $(\mu \mathrm{m})$} \\
\cline { 2 - 3 } & Red Lentil Flour & Yellow Pea Flour \\
\hline Small & $56.05 \pm 3.59$ & $41.38 \pm 0.56$ \\
Medium & $67.01 \pm 3.29$ & $60.81 \pm 2.02$ \\
Large & $97.17 \pm 2.6$ & $98.31 \pm 0.87$ \\
\hline
\end{tabular}

It is evident from Figures 3 and 4 that $100 \%$ of all the flour types from red lentils and yellow peas were below the $212 \mu \mathrm{m}$ range. The two peaks observed in Figure 3 for all three flour types (S, M, and L) of red lentil flours indicates a bimodal distribution at $53 \mu \mathrm{m}$ and $125 \mu \mathrm{m}$. The larger peaks at $53 \mu \mathrm{m}$ might be attributed to the release of small starch particles (below $53 \mu \mathrm{m}$ ) from the kernel matrix, and the smaller peaks at $125 \mu \mathrm{m}$ could be pulse protein or starch and protein aggregates. A similar pattern was observed in case of wheat, where other researchers have reported that starch granules ranging from 2 to $38 \mu \mathrm{m}$ in diameter were found in the first peak of particle size distribution [28-30].

In case of yellow pea flours, the bimodal distribution was observed for medium and large flour types. Only the first peaks of all three flour types matched at $53 \mu \mathrm{m}$, whereas the second peaks for medium and large flours were obtained near $125 \mu \mathrm{m}$ and $175 \mu \mathrm{m}$, respectively. The small flour showed a unique pattern of unimodal distribution with a single peak at $53 \mu \mathrm{m}$, as shown in Figure 4 . The amount of flour that passed through the $53 \mu \mathrm{m}$ sieve for small flour was more than $80 \%$, leading to a unimodal distribution. Overall, for both the pulse types, slightly more than $50 \%$ flour was sized around $50 \mu \mathrm{m}, 75 \mu \mathrm{m}$, and $100 \mu \mathrm{m}$ for small, medium, and large settings, respectively, fulfilling the objective of the study.

\subsection{Pulse Flour Quality Evaluation}

\subsubsection{Red Lentil Flour Quality}

A physicochemical analysis of small, medium, and large red lentil flours as a function of particle size is presented in Table 4. From Tables 1 and 4, the effect of milling on the physicochemical properties of lentils can be clearly observed. The moisture of the grains decreased from $12 \%$ to $9.9 \%$ (small), 10.04 (medium) and 9.39 (large) post milling. A higher reduction of moisture content was observed in case of large mill settings. This loss of moisture could be due to the generation of heat during the milling process. There was an increase in fat content in resultant flours $(0.68$ to $0.98 \%)$ compared to the grain $(0.38 \%)$. The removal of husk and potential contamination with germ portions might have caused this slight increase in fat values. 


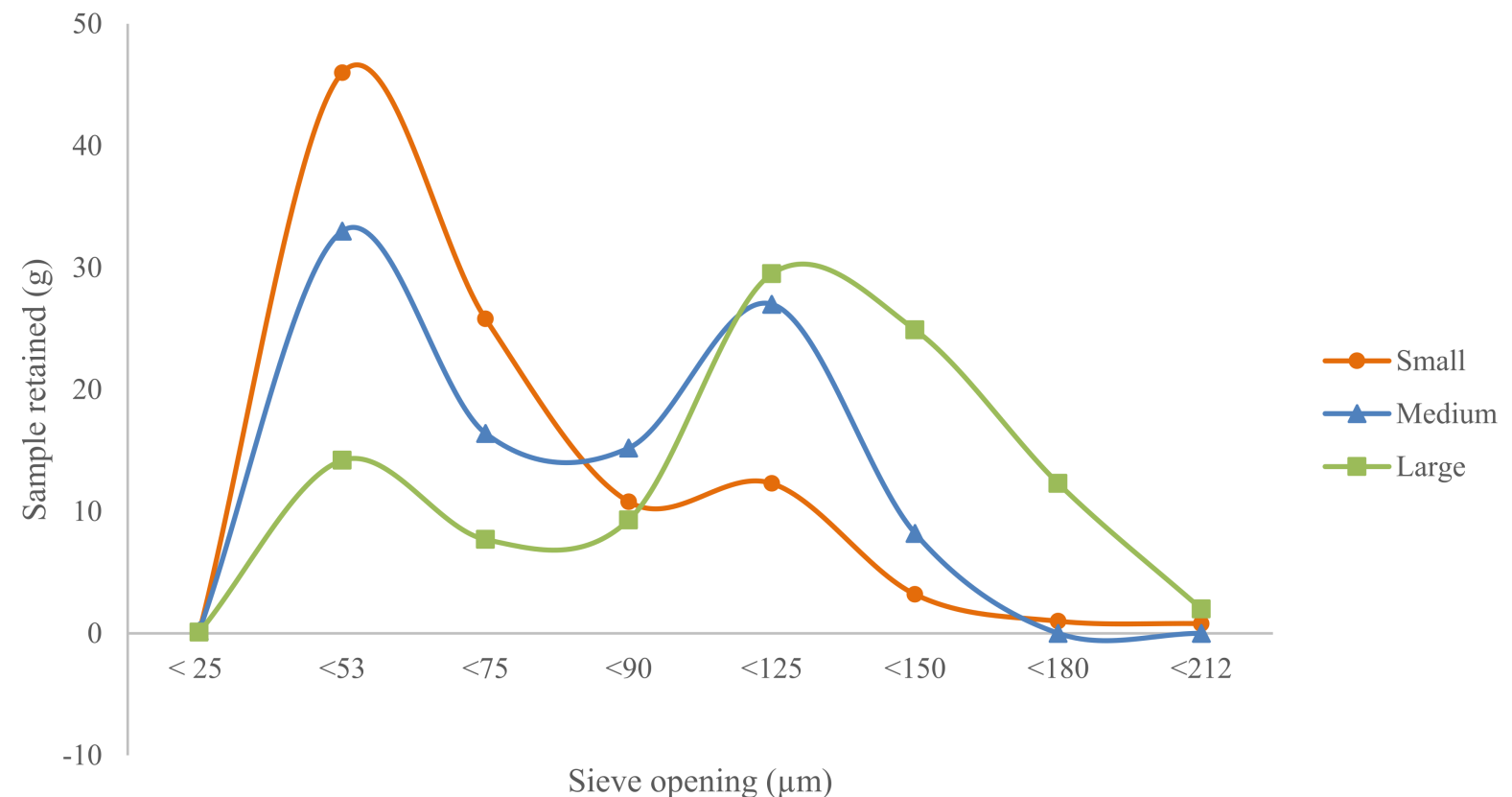

Figure 3. Particle size distribution of small, medium, and large red lentil flour.

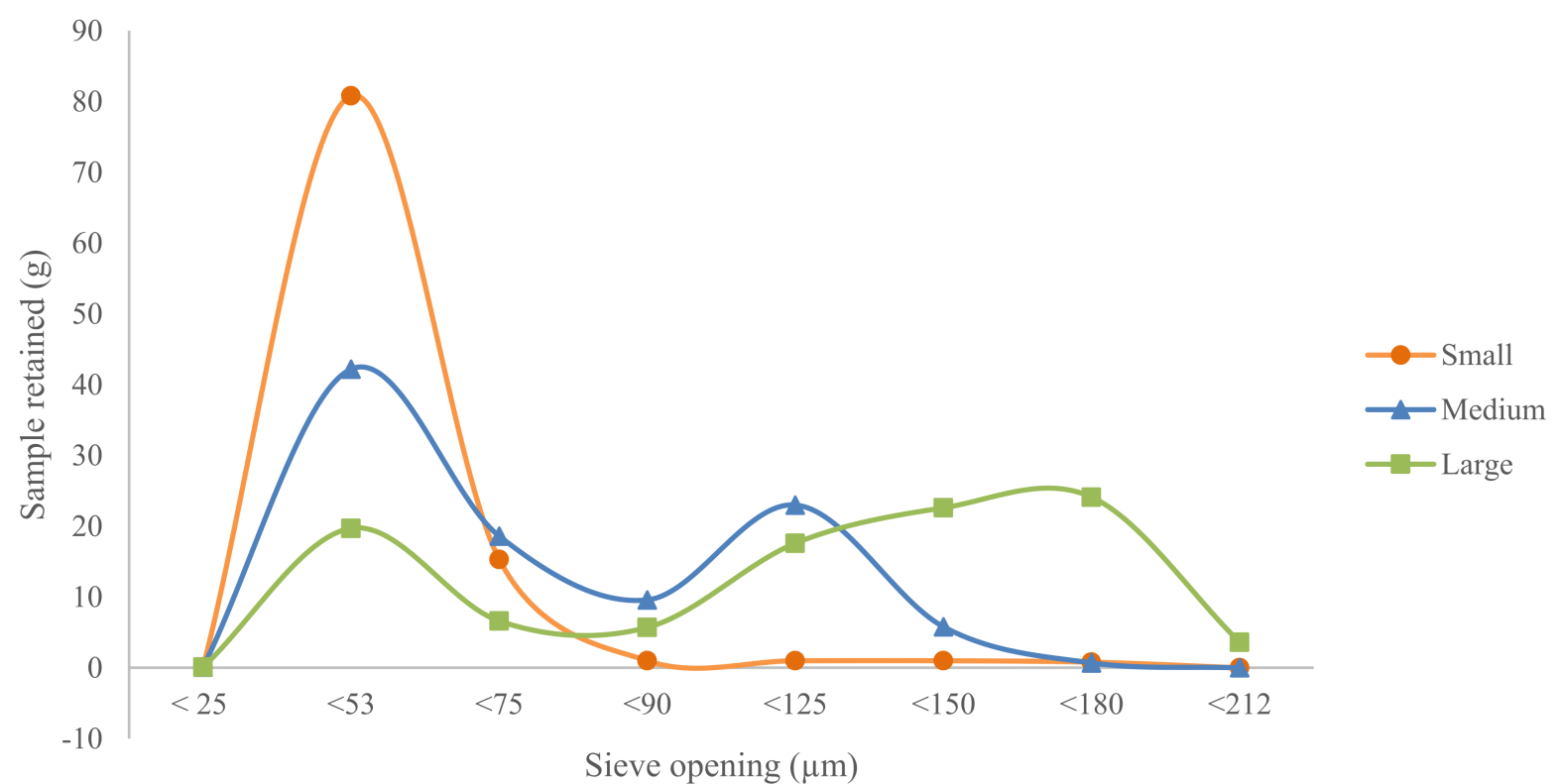

Figure 4. Particle size distribution of small, medium, and large yellow pea flour.

The proximate composition (except for carbohydrates) of the flours did not alter significantly $(p \leq 0.05)$ with varying size of flours. The protein values of all the lentil flours ranged from 25.47 to $25.71 \%$. The study conducted by Marchini et al. [10] showed that the protein content of the red lentil flours increased (21.21\% to $24.06 \%$ ) with decrease in particle sizes of the flour from $\geq 200 \mu \mathrm{m}$ fraction to below $\leq 100 \mu \mathrm{m}$ fraction. However, in the present study, the designed mill settings have helped in achieving significantly similar values supporting the objective of this study. The crude fiber content varied from 0.85 to $0.97 \%$, a significant reduction compared to the whole lentils (Table 1) due to the removal of husk portions from the flour. The ash content of the flours altered between 2.04 and $2.19 \%$, close to the range indicated by Ahmed et al. [11]. However, the fat contents $(0.68-0.98 \%)$ of the lentil flours obtained were lower compared to the values reported in 
literature $[10,11]$. This could be due to the greater separation of germ portions in the form of shorts during the sifting process. As expected, the starch damage significantly increased from 3.41 to $5.47 \%$ with decrease in the particle size of flour. This trend agrees with the study reported by Bourré et al. [12] on yellow pea and red lentil flours of different particle sizes. The proximate composition of all lentil flours agreed with the results reported by Bourré et al. [12] and Hall et al. [31], except for crude fiber and fat. The lightness values of the red lentil flour varied significantly $(p \leq 0.05)$ for small and large mill settings. Conversely, $\mathrm{a}^{*}$ and $\mathrm{b}^{*}$ values of the medium and large remained unchanged, showing no statistical significance $(p \leq 0.05)$.

Table 4. Physicochemical properties of red lentil flours.

\begin{tabular}{|c|c|c|c|}
\hline \multirow{2}{*}{ Test Variable } & \multicolumn{3}{|c|}{ Red Lentil Flour } \\
\hline & $\mathbf{S}$ & $\mathbf{M}$ & $\mathbf{L}$ \\
\hline Moisture (\% wet basis) & $9.90 \pm 0.1^{\mathrm{a}}$ & $10.04 \pm 0.04^{\mathrm{a}}$ & $9.39 \pm 0.22^{b}$ \\
\hline Crude protein (\%) & $25.50 \pm 0.11^{\mathrm{a}}$ & $25.47 \pm 0.11^{\mathrm{a}}$ & $25.71 \pm 0.12^{\mathrm{a}}$ \\
\hline Crude fat $(\%)$ & $0.98 \pm 0.14^{\mathrm{a}}$ & $0.98 \pm 0.04^{\mathrm{a}}$ & $0.68 \pm 0.22^{a}$ \\
\hline Crude fiber $(\%)$ & $0.85 \pm 0.1^{\mathrm{a}}$ & $0.90 \pm 0.02^{a}$ & $0.97 \pm 0.08^{a}$ \\
\hline $\begin{array}{l}\text { Total carbohydrates excluding } \\
\text { crude fiber (\%) }\end{array}$ & $60.73 \pm 0.2^{\mathrm{ab}}$ & $60.41 \pm 0.13^{b}$ & $61.08 \pm 0.35^{\mathrm{a}}$ \\
\hline $\operatorname{Ash}(\%)$ & $2.04 \pm 0.33^{\mathrm{a}}$ & $2.19 \pm 0.05^{\mathrm{a}}$ & $2.16 \pm 0.01^{\mathrm{a}}$ \\
\hline Damaged starch (AACC) & $5.47 \pm 0.13^{\mathrm{a}}$ & $4.19 \pm 0.30^{b}$ & $3.41 \pm 0.13^{b}$ \\
\hline $\mathrm{L}^{*}(0-$ black to 100 -white $)$ & $80.54 \pm 0.51^{a}$ & $79.14 \pm 0.61^{\mathrm{ab}}$ & $77.96 \pm 0.79^{b}$ \\
\hline $\mathrm{a}^{*}($-green to + red $)$ & $11.09 \pm 0.05^{b}$ & $13.88 \pm 0.12^{\mathrm{a}}$ & $14.33 \pm 0.52^{\mathrm{a}}$ \\
\hline $\mathrm{b}^{*}$ (-blue to +yellow) & $26.57 \pm 0.04^{b}$ & $29.88 \pm 0.29^{a}$ & $30.31 \pm 0.90^{\mathrm{a}}$ \\
\hline Bulk density $\left(\mathrm{kg} / \mathrm{m}^{3}\right)$ & $487 \pm 1.41^{c}$ & $566 \pm 1.41^{b}$ & $576 \pm 1.41^{\mathrm{a}}$ \\
\hline Tap density $\left(\mathrm{kg} / \mathrm{m}^{3}\right)$ & $735 \pm 0.00^{b}$ & $773.5 \pm 3.53^{\mathrm{a}}$ & $764 \pm 2.83^{a}$ \\
\hline True density $\left(\mathrm{kg} / \mathrm{m}^{3}\right)$ & $1456.6 \pm 0.37^{a}$ & $1453 \pm 0.15^{\mathrm{c}}$ & $1454.3 \pm 0.2^{b}$ \\
\hline Hausner ratio & $1.51 \pm 0.00^{\mathrm{a}}$ & $1.37 \pm 0.00^{b}$ & $1.33 \pm 0.00^{c}$ \\
\hline Porosity & $66.56 \pm 0.11^{\mathrm{a}}$ & $61.05 \pm 0.1^{b}$ & $60.39 \pm 0.1^{c}$ \\
\hline
\end{tabular}

The different super scripts for mean values in each row are significantly different $(p \leq 0.05)$.

The bulk density values of the flours significantly $(p \leq 0.05)$ increased with increase in particle size. The smaller the particle size of the flour, higher the inter-particle spaces, resulting in lower test weight or bulk densities. The true density values of the powders significantly changed $(p \leq 0.05)$ with varying particle size. The specifications based on Hausner's ratio for flowability from Lebrun et al.'s [32] study suggest that the small (1.51) and medium flours (1.37) fall under the category of "very poor" and "poor", respectively. However, large (1.33) flours fall into "passable" category.

\subsubsection{Yellow Pea Flour Quality}

The proximate composition and physical properties of the small, medium, and large yellow pea flours as a function of particle size are shown in Table 5. The differences in proximate compositions of the grain and flour samples are evident from Tables 1 and 5 . The moisture contents of the yellow peas (12\%) were reduced to $11.1-11.22 \%$ for the yellow pea flours. The highest moisture loss was observed for small mill settings. The reason for this loss of moisture is same as discussed above for lentils. The crude fiber content reduced from $5.29 \%$ (grains) to a range of $1.11-1.19 \%$ (flours) post milling. The removal of husk during milling process led to these decreased fiber values in the final flour fractions. 
Table 5. Physicochemical properties of yellow pea flours.

\begin{tabular}{|c|c|c|c|}
\hline \multirow{2}{*}{ Test Variable } & \multicolumn{3}{|c|}{ Yellow Pea Flour } \\
\hline & S & $\mathbf{M}$ & $\mathbf{L}$ \\
\hline Moisture (\% wet basis) & $11.10 \pm 0.08^{a}$ & $11.14 \pm 0.05^{\mathrm{a}}$ & $11.22 \pm 0.09^{a}$ \\
\hline Crude protein $(\%)$ & $21.58 \pm 0.12^{b}$ & $22.03 \pm 0.01^{\mathrm{a}}$ & $21.25 \pm 0.08^{c}$ \\
\hline Crude fat $(\%)$ & $0.91 \pm 0.09^{a}$ & $0.81 \pm 0.15^{\mathrm{a}}$ & $0.50 \pm 0.11^{\mathrm{b}}$ \\
\hline Crude fiber $(\%)$ & $1.19 \pm 0.03^{\mathrm{a}}$ & $1.18 \pm 0.06^{\mathrm{a}}$ & $1.11 \pm 0.04^{\mathrm{a}}$ \\
\hline $\begin{array}{c}\text { Total carbohydrates excluding } \\
\text { crude fiber }(\%)\end{array}$ & $62.78 \pm 0.13^{b}$ & $62.35 \pm 0.13^{c}$ & $63.42 \pm 0.12^{\mathrm{a}}$ \\
\hline $\operatorname{Ash}(\%)$ & $2.43 \pm 0.02^{\mathrm{a}}$ & $2.51 \pm 0.06^{\mathrm{a}}$ & $2.50 \pm 0.01^{\mathrm{a}}$ \\
\hline Damaged starch (AACC) & $9.05 \pm 0.28^{\mathrm{a}}$ & $7.10 \pm 0.02^{b}$ & $5.90 \pm 0.66^{c}$ \\
\hline $\mathrm{L}^{*}$ (0- black to 100 -white $)$ & $83.61 \pm 0.53^{a}$ & $82.6 \pm 0.62^{\mathrm{a}}$ & $83.11 \pm 1.23^{a}$ \\
\hline $\mathrm{a}^{*}($-green to $+\mathrm{red})$ & $1.56 \pm 0.04^{b}$ & $1.65 \pm 0.09^{b}$ & $2.19 \pm 0.06^{\mathrm{a}}$ \\
\hline $\mathrm{b}^{*}$ (-blue to +yellow) & $22.22 \pm 0.28^{b}$ & $22.70 \pm 0.32^{b}$ & $25.27 \pm 0.58^{\mathrm{a}}$ \\
\hline Bulk density $\left(\mathrm{kg} / \mathrm{m}^{3}\right)$ & $440.5 \pm 4.95^{b}$ & $451.5 \pm 4.96^{b}$ & $468.5 \pm 0.71^{\mathrm{a}}$ \\
\hline Tap density $\left(\mathrm{kg} / \mathrm{m}^{3}\right)$ & $687.5 \pm 3.54^{\mathrm{a}}$ & $681.5 \pm 4.95^{\mathrm{a}}$ & $678 \pm 5.66^{\mathrm{a}}$ \\
\hline True density $\left(\mathrm{kg} / \mathrm{m}^{3}\right)$ & $1469.63 \pm 1.76^{\mathrm{a}}$ & $1458.07 \pm 0.51^{b}$ & $1459.6 \pm 0.92^{b}$ \\
\hline Hausner ratio & $1.56 \pm 0.01^{\mathrm{a}}$ & $1.51 \pm 0.01^{\mathrm{b}}$ & $1.45 \pm 0.01^{\mathrm{c}}$ \\
\hline Porosity & $70.02 \pm 0.29^{a}$ & $69.03 \pm 0.35^{\mathrm{a}}$ & $67.89 \pm 0.07^{b}$ \\
\hline
\end{tabular}

The different super scripts for mean values in each row are significantly different $(p \leq 0.05)$.

The proximate composition of the flours altered significantly $(p \leq 0.05)$, with varying flour sizes, except for crude fiber, ash, and moisture values. Even though there is statistically significant difference $(p \leq 0.05)$ between protein, fat, and carbohydrates, the variation can be considered to be negligible in a practical industry setting. The proximate composition of yellow pea flour was in concordance with the values of de-husked yellow pea flour obtained through roller milling by Motte et al. [33]. The protein values of yellow pea flours ranged from 21.25 to $22.03 \%$. Similar to the red lentil flours, the crude fiber content was reduced considerably compared to the whole yellow pea kernels (Table 1) and can be attributed to the de-husking of pulses. The ash content of the yellow pea flours lay between 2.43 and $2.51 \%$, higher than the red lentil flours reported in Table 4 . These results closely agreed with ash values reported for untreated yellow pea flours by $\mathrm{Xu}$ et al. [34].

The fat contents of the yellow pea flour ranged from $0.50-0.91 \%$, with no statistical difference between small and medium flours. The reason for significantly lower fat content in large yellow pea flour $(0.50 \%)$ compared to small $(0.91 \%)$ and medium flours $(0.81 \%)$ could be due to the efficient separation of germ portions for large mill settings. The starch damage significantly increased from 5.9 to $9.05 \%$ as particle size of the flours decreased from large to smaller size. The red lentil flours also followed a similar pattern in damaged starch values with increase in fineness of the flour. A similar trend of higher damaged starch was attributed to smaller particle size of yellow pea and lentil flours by Motte et al. [33]. This same effect was most commonly reported by various researchers for wheat milling [35-37]. The increase in damaged starch values for finer flours can be explained by the greater impact of mechanical damage due to decreased roller gaps. The damaged starch values in milling play an important role in understanding the effectiveness of milling. Lower starch damage is more preferable in the final flour fraction because the dough mixing and pasting properties are greatly affected, resulting in the poor color and firmness of final food products $[38,39]$. The starch damage values of large flour match with the study conducted by $\mathrm{Gu}$ et al. [38] on yellow peas.

The lightness values of the yellow pea flour did not show any statistical significance $(p \leq 0.05)$ with respect to particle size as a function. Additionally, the $\mathrm{a}^{*}$ and $\mathrm{b}^{*}$ values of small and medium flours remained constant with no statistical significance $(p \leq 0.05)$.

The bulk density values of the small and medium flours remained unchanged $(p \leq 0.05)$ with increase in particle size. However, the large flour exhibited a significantly $(p \leq 0.05)$ higher bulk density value. The tap density values of all the three types of flours observed no statistical significance $(p \leq 0.05)$, whereas the true density value of small flour was 
found to be significantly $(p \leq 0.05)$ higher than the other two flours. Based on Hausner's ratio, the small (1.56) and medium (1.51) flours fall into "very poor" category and the large (1.45) flour can be considered as "poor" in terms of flowability [32].

\section{Conclusions}

The current study explored the possibility of adapting roller milling to produce dehusked red lentil and yellow pea flours. The particle size of all the flour sizes were restricted to below $212 \mu \mathrm{m}$ as per the wheat flour definition given by the Code of Federal Regulations. The individual flowsheets were developed for each type of pulse with three different desired particle sizes. The milling flowsheets helped in achieving similar proximate compositions for the three different flours. The flour quality evaluation was also conducted to understand the effect of milling on some important physicochemical properties. The particle size analysis and geometric mean diameter showed a clear understanding of the particle sizes of all flour types for further end applications. These findings assist the wheat millers to adapt yellow pea and red lentil milling technologies with minor modifications to the existing facilities. The study also helps in boosting the production of various baking products using pulse and wheat flour blends to enhance the nutritional quality.

Author Contributions: Conceptualization, M.K.P., Y.L. and K.S.; methodology, M.K.P., J.W., Y.L. and K.S.; software, M.K.P., Y.L. and K.S.; validation, M.K.P., E.N., Y.L. and K.S.; formal analysis, M.K.P. and K.S.; investigation, M.K.P., E.N., Y.L. and K.S.; resources, J.W., Y.L. and K.S.; data curation, M.K.P.; writing—original draft preparation, M.K.P.; writing—review and editing, M.K.P., E.N., Y.L. and K.S.; visualization, M.K.P.; lead supervision, K.S.; supervision, Y.L.; project administration, K.S. and Y.L.; funding acquisition, K.S. and Y.L. All authors have read and agreed to the published version of the manuscript.

Funding: This research was in part funded by the USDA Pulse Crop Health Initiative (PCHI), grant number 58-3060-0-051 and also KS00-0056-NC213 USDA HATCH project" and "The APC was funded by the USDA Pulse Crop Health Initiative (PCHI), grant number 58-3060-0-051.

Institutional Review Board Statement: Not applicable.

Informed Consent Statement: Not applicable.

Data Availability Statement: The data presented in this study are available on request from the corresponding author.

Acknowledgments: This is contribution No. 22-094-J from the Kansas Agricultural Experimental Station.

Conflicts of Interest: The authors declare no conflict of interest.

\section{References}

1. Rutherfurd, S.M.; Bains, K.; Moughan, P.J. Available lysine and digestible amino acid contents of proteinaceous foods of India. Br. J. Nutr. 2012, 108, S59-S68. [CrossRef] [PubMed]

2. Tiwari, B.K.; Singh, N. Pulse Chemistry and Technology; Royal Society of Chemistry: Cambridge, UK, 2012.

3. Temba, M.C.; Njobeh, P.B.; Adebo, O.A.; Olugbile, A.O.; Kayitesi, E. The role of compositing cereals with legumes to alleviate protein energy malnutrition in Africa. Int. J. Food Sci. Technol. 2016, 51, 543-554. [CrossRef]

4. Herranz, B.; Canet, W.; Jiménez, M.J.; Fuentes, R.; Alvarez, M.D. Characterisation of chickpea flour-based gluten-free batters and muffins with added biopolymers: Rheological, physical and sensory properties. Int. J. Food Sci. Technol. 2016, 51, 1087-1098. [CrossRef]

5. Giménez, M.A.; Drago, S.R.; De Greef, D.; Gonzalez, R.J.; Lobo, M.O.; Samman, N.C. Rheological, functional and nutritional properties of wheat/broad bean (Vicia faba) flour blends for pasta formulation. Food Chem. 2012, 134, 200-206. [CrossRef]

6. Zucco, F.; Borsuk, Y.; Arntfield, S.D. Physical and nutritional evaluation of wheat cookies supplemented with pulse flours of different particle sizes. LWT-Food Sci. Technol. 2011, 44, 2070-2076. [CrossRef]

7. Zhang, Y.; Hu, R.; Tilley, M.; Siliveru, K.; Li, Y. Effect of Pulse Type and Substitution Level on Dough Rheology and Bread Quality of Whole Wheat-Based Composite Flours. Processes 2021, 9, 1687. [CrossRef]

8. Maskus, H.; Bourre, L.; Fraser, S.; Ashok, S.; Malcolmson, L. Effects of grinding method on the compositional, physical, and functional properties of whole and split yellow pea flours. Cereal Foods World 2016, 61, 59-64. [CrossRef] 
9. Campbell, G.M.; Bunn, P.J.; Webb, C.; Hook, S.C.W. On predicting roller milling performance: Part II. The breakage function. Powder Technol. 2001, 115, 243-255. [CrossRef]

10. Marchini, M.; Carini, E.; Cataldi, N.; Boukid, F.; Blandino, M.; Ganino, T.; Vittadini, E.; Pellegrini, N. The use of red lentil flour in bakery products: How do particle size and substitution level affect rheological properties of wheat bread dough? LWT-Food Sci. Technol. 2021, 136, 110299. [CrossRef]

11. Ahmed, J.; Taher, A.; Mulla, M.Z.; Al-Hazza, A.; Luciano, G. Effect of sieve particle size on functional, thermal, rheological and pasting properties of Indian and Turkish lentil flour. J. Food Eng. 2016, 186, 34-41. [CrossRef]

12. Bourré, L.; Frohlich, P.; Young, G.; Borsuk, Y.; Sopiwnyk, E.; Sarkar, A.; Nickerson, M.T.; Ai, Y.; Dyck, A.; Malcolmson, L. Influence of particle size on flour and baking properties of yellow pea, navy bean, and red lentil flours. Cereal Chem. 2019, 96, 655-667. [CrossRef]

13. Mohsenin, N.N. Physical Properties of Plant and Animal Materials; Gordon and Breach Science Publishers: New York, NY, USA, 1970 .

14. Cereals \& Grains Association. AACC Approved Methods of Analysis, 11th ed.; Method 44-19.01: Moisture-Air-Oven Method, Drying at 135; Cereals \& Grains Association: St. Paul, MN, USA, 1999.

15. Cereals \& Grains Association. AACC Approved Methods of Analysis, 11th ed.; Method 46-30.01: Crude Protein-Combustion Method; Cereals \& Grains Association: St. Paul, MN, USA, 1999.

16. Cereals \& Grains Association. AACC Approved Methods of Analysis, 11th ed.; Method 30-10.01: Crude Fat in Flour, Bread, and Baked Cereal Products Not Containing Fruit; Cereals \& Grains Association: St. Paul, MN, USA, 1999.

17. Cereals \& Grains Association. AACC Approved Methods of Analysis, 11th ed.; Method: 32-10.01: Crude Fiber in Flour, Bread, and Baked Cereal Products Not Containing Fruit; Cereals \& Grains Association: St. Paul, MN, USA, 1999.

18. Cereals \& Grains Association. AACC Approved Methods of Analysis, 11th ed.; Method 08-01.01: Ash-Basic Method; Cereals \& Grains Association: St. Paul, MN, USA, 2009.

19. Cereals \& Grains Association. AACC Approved Methods of Analysis, 11th ed.; Method 76-33.01: Damaged Starch-Amperometric Method by SDmatic; Cereals \& Grains Association: St. Paul, MN, USA, 2011.

20. Rivera, J.; Deliephan, A.; Dhakal, J.; Aldrich, C.G.; Siliveru, K. Significance of Sodium Bisulfate (SBS) Tempering in Reducing the Escherichia coli O121 and O26 Load of Wheat and Its Effects on Wheat Flour Quality. Foods 2021, 10, 1479. [CrossRef] [PubMed]

21. Patwa, A.; Malcolm, B.; Wilson, J.; Ambrose, K.R. Particle size analysis of two distinct classes of wheat flour by sieving. Trans. ASABE 2014, 57, 151-159.

22. Dziki, D.; Laskowski, J. Wheat kernel physical properties and milling process. Acta Agrophysica 2005, 6, 59-71.

23. Gürsoy, S.; Güzel, E. Determination of physical properties of some agricultural grains. Res. J. Appl. Sci. Eng. Technol. 2010, 2, 492-498.

24. Kumar, M.M.; Prasad, K.; Chandra, T.S.; Debnath, S. Evaluation of physical properties and hydration kinetics of red lentil (Lens culinaris) at different processed levels and soaking temperatures. J. Saudi Soc. Agric. Sci. 2018, 17, 330-338.

25. Roy, F.; Boye, J.I.; Simpson, B.K. Bioactive proteins and peptides in pulse crops: Pea, chickpea and lentil. Food Res. Int. 2010, 43, 432-442. [CrossRef]

26. Thakur, S.; Scanlon, M.G.; Tyler, R.T.; Milani, A.; Paliwal, J. Pulse flour characteristics from a wheat flour miller's perspective: A comprehensive review. Compr. Rev. Food Sci. Food Saf. 2019, 18, 775-797. [CrossRef]

27. Food and Drug Administration (FDA). Code of Federal Regulations Title 21; Sec 137.105 Flour. Available online: https:/ /www. ecfr.gov/current/title-21/chapter-I/subchapter-B/part-137 (accessed on 10 October 2021).

28. Kim, W.; Choi, S.G.; Kerr, W.L.; Johnson, J.W.; Gaines, C.S. Effect of heating temperature on particle size distribution in hard and soft wheat flour. J. Cereal Sci. 2004, 40, 9-16. [CrossRef]

29. Peng, M.; Gao, M.; Abdel-Aal, E.S.; Hucl, P.; Chibbar, R.N. Separation and characterization of A-and B-type starch granules in wheat endosperm. Cereal Chem. 1999, 76, 375-379. [CrossRef]

30. Raeker, M.Ö.; Gaines, C.S.; Finney, P.L.; Donelson, T. Granule size distribution and chemical composition of starches from 12 soft wheat cultivars. Cereal Chem. 1998, 75, 721-728. [CrossRef]

31. Hall, C.; Hillen, C.; Garden Robinson, J. Composition, nutritional value, and health benefits of pulses. Cereal Chem. 2017, 94, 11-31. [CrossRef]

32. Lebrun, P.; Krier, F.; Mantanus, J.; Grohganz, H.; Yang, M.; Rozet, E.; Boulanger, B.; Evrard, B.; Rantanen, J.; Hubert, P. Design space approach in the optimization of the spray-drying process. Eur. J. Pharm. Biopharm. 2012, 80, 226-234. [CrossRef] [PubMed]

33. Motte, J.C.; Tyler, R.; Milani, A.; Courcelles, J.; Der, T. Pea and lentil flour quality as affected by roller milling configuration. Legume Sci. 2021, 1-15. [CrossRef]

34. Xu, M.; Jin, Z.; Simsek, S.; Hall, C.; Rao, J.; Chen, B. Effect of germination on the chemical composition, thermal, pasting, and moisture sorption properties of flours from chickpea, lentil, and yellow pea. Food Chem. 2019, 295, 579-587. [CrossRef] [PubMed]

35. Siliveru, K.; Ambrose, R.K.; Vadlani, P.V. Significance of composition and particle size on the shear flow properties of wheat flour. J. Sci. Food Agric. 2017, 97, 2300-2306. [CrossRef]

36. Kuakpetoon, D.; Flores, R.A.; Milliken, G.A. Dry mixing of wheat flours: Effect of particle properties and blending ratio. LWT-Food Sci. Technol. 2001, 34, 183-193. [CrossRef]

37. Wang, L.; Flores, R.A. Effects of flour particle size on the textural properties of flour tortillas. J. Cereal Sci. 2000, 31, $263-272$. [CrossRef] 
38. Gu, Z.; Jiang, H.; Zha, F.; Manthey, F.; Rao, J.; Chen, B. Toward a comprehensive understanding of ultracentrifugal milling on the physicochemical properties and aromatic profile of yellow pea flour. Food Chem. 2021, 345, 128760. [CrossRef]

39. Deng, L.; Manthey, F.A. Laboratory-scale milling of whole-durum flour quality: Effect of mill configuration and seed conditioning. J. Sci. Food Agric. 2017, 97, 3141-3150. [CrossRef] 